\title{
TEXTILE FINDS FROM THE EARLY MEDIEVAL CEMETERY IN GLINNO, SIERADZ DISTRICT. NEW DATA FOR THE RESEARCH ON TEXTILE PRODUCTION IN CENTRAL POLAND
}

\begin{abstract}
The present paper is devoted to a detailed discussion of a set of textile remains (5 fragments) from the inhumation cemetery in Glinno, Site 15, Sieradz District, Łódzkie Voivodeship (mid-11 $1^{\text {th }}-$ mid- $12^{\text {th }}$ century). They were discovered in Graves 1-2 and 18. All discussed textile remains were found to be in a poor state of preservation. Despite that, the analysis revealed that these were local products characteristic for domestic production whose quality does not differ from other products from Central Poland. Their function is not clear; however, the textile fragments from the inside of a knife sheath and the knife possibly indicate technical textile (lining). In the case of other textile finds, a funeral function should be generally presumed, considering a high probability that the objects were wrapped in a piece of cloth.
\end{abstract}

Keywords: cemetery, Early Middle Ages, archaeological textiles, weaving techniques, burial rite, Central Poland

Textile products are a kind of finds which hardly survive at archaeological sites. The state of degradation of textile products depends on the environment conditions and post-depositional processes to which they were subjected. ${ }^{1}$ This is why even the tiniest fragment of textile discovered during excavation works or observed in the archaeological evidence significantly expands our source basis for research on the production and use of textiles in the past.

The present paper offers a detailed discussion of the set of textile remains from the inhumation cemetery in Glinno, Site 15 (Sieradz District, Łódzkie Voivodeship), ${ }^{2}$ preliminarily dated to the mid- $11^{\text {th }}$ and mid- $12^{\text {th }}$ century. ${ }^{3}$

The site was accidentally discovered during ground works related to a construction of a summer house in 2000 .

* Institute of Archaeology and Ethnology, Polish Academy of Sciences, Łódź; (D https://orcid.org/0000-0003-4781-0476; 1.antos@wp.pl

** Institute of Archaeology and Ethnology, Polish Academy of Sciences, Łódź; (D https://orcid.org/0000-0002-8158-1104; tomasz.kurasinski@wp.pl

${ }^{1}$ See Peacock 2014.

${ }^{2}$ Macro- and microscopic analyses were carried out, see Maik 2000; Antosik 2014.

${ }^{3}$ We would like to thank Dr Zbigniew Lechowicz from the Regional Centre of Study and Documentation of Historical Monuments in Łódź for granting us access to the finds. An extensive study of the site is under preparation.
What was found were human remains and several temple rings; rescue excavations ensued in the accessible area.

The cemetery is situated on the border of the right side of the Warta river valley, in the backwater area of the Jeziorsko reservoir. It is located partly in the area of recreational plots with legal permission for the construction of permanent housing, and partly on adjacent farming lands (Fig. 1).

In total, 20 inhumation graves (including a double one) in various states of preservation were discovered in the excavated area. Total destruction of bones occurred in some of the grave pits. ${ }^{4}$ Only a small part of the site could be examined, and consequently the discovered graves only constitute a fragment of the cemetery which is presumed to continue in the northern and western direction. Despite the limited area of examination, the cemetery layout was determined to be based on rows (see Fig. 2).

In a majority of cases, the deceased were found with grave goods. These included objects of daily use (mainly iron knives), containers (ceramic and stave vessels), as well as a set of decorative items having various functions and made of various materials. Additionally, a coin and an axe head

\footnotetext{
${ }^{4}$ Traces of prehistoric settlement related to the Lusatian Culture (pits) and the Przeworsk Culture (ceramic vessel shards) were also found at the site.
} 


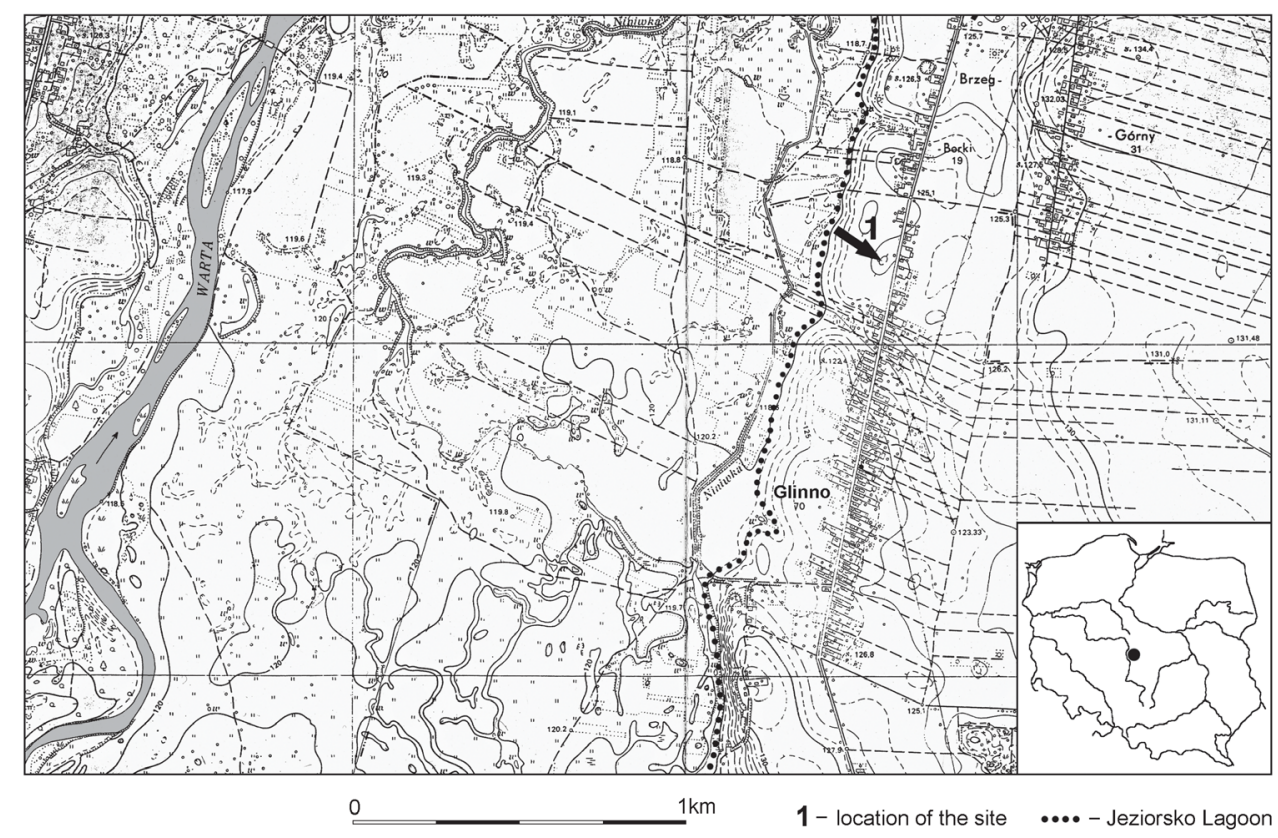

Fig. 1. Location of the cemetery in Glinno. Drawing and processing E. Wtorkiewicz-Marosik.

were found. ${ }^{5}$ Other finds include organic remains, among which the mentioned textile finds deserve particular attention. They were recorded in Graves 1-2 and 18 (Fig. 2).

Two bodies were buried in the first grave: most likely, of a man (30-40 years old) and a woman (14-16 years old). The

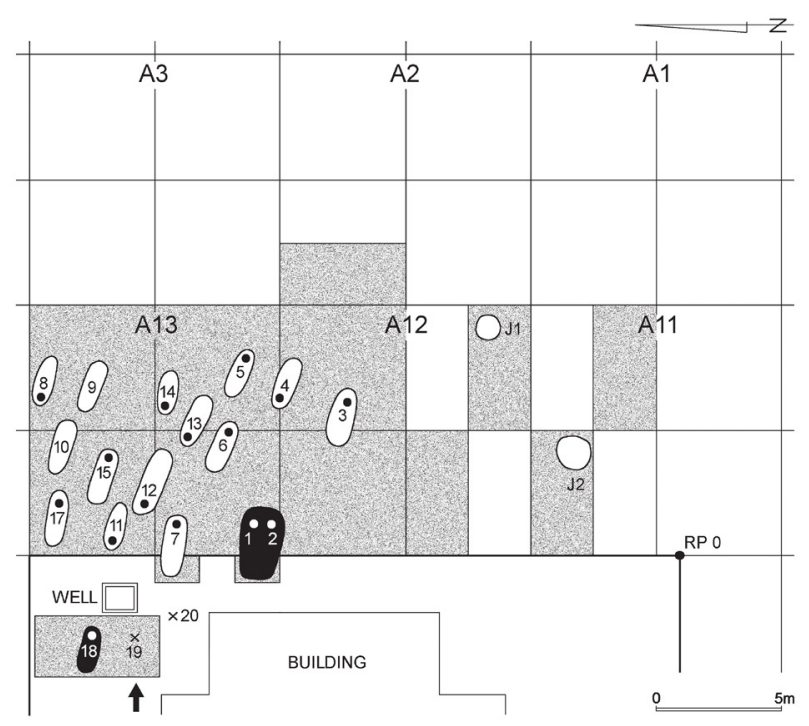

Fig. 2. Plan of the cemetery in Glinno - graves with textile finds. Processing E. Wtorkiewicz-Marosik.

\footnotetext{
${ }^{5}$ Some of these artefacts are discussed in a separate publication, Kurasiński 2015; Kurasiński 2016.
}

woman's body was accompanied by a silver temple ring, a ceramic vessel and an iron knife. The man was buried with a stave bucket (near his right foot) and an iron knife, the fragments of which were found inside a metal-mounted decorative sheath placed to the left of the man's pelvis. The sheath must have been covered with a brass sheet along its entire length. Its ending was reinforced with a rectangular fitting, and the sheath's construction included a core adorned with incisions. Fragments of intensively mineralised textiles were documented on the $\mathrm{knife}^{6}$ as well as under and on the surface of the sheath's brass fitting. Moreover, a fragile textile fragment was observed under the layer of sheath's leather (Figs. 3:A; 4:A).

In Grave 18, strongly decomposed remains of a man deceased at the age of 50 were identified. An iron knife was discovered near the skeleton, though there is no information about its detailed location. It is not documented, either, where the bucket with iron construction elements (handle, hoops, loops) and decorative elements (band, applications) was situated. Remains of a mineralised textile were observed on the end of a crescent-shaped metal application (on the external surface), that is, in the upper part of the container (Figs. 3:B; 4:B).

Excavation works in the Glinno cemetery brought the discovery of five textile remains in total. Being so small, the set nevertheless significantly completes the source basis of early medieval textile finds from the territory of Central Poland. So far, only 86 textile fragments from this territory

\footnotetext{
${ }^{6}$ Several textile fragments were found on the knife. The largest one has been preserved in three layers; according to J. Maik, it means that the textile was folded in this place, Maik 2000.
} 


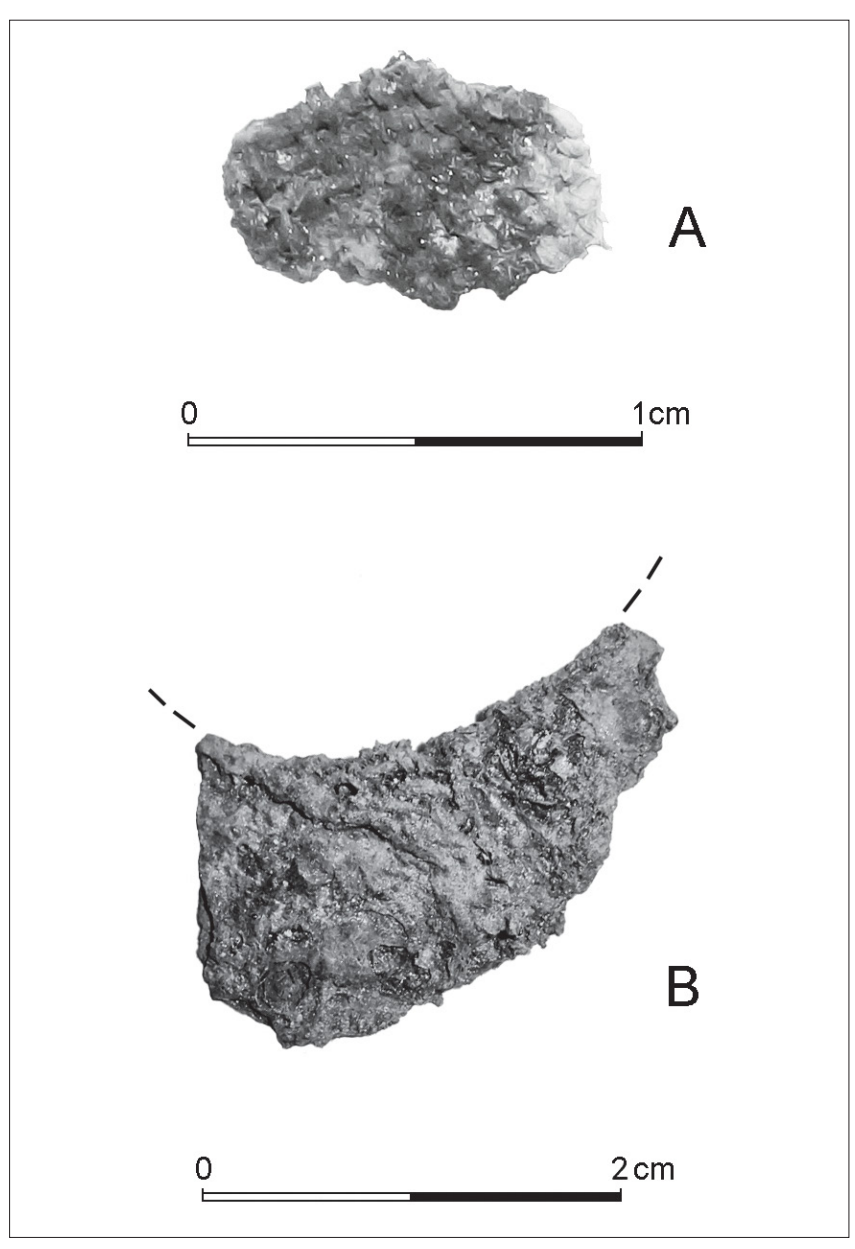

Fig. 3. Cemetery in Glinno: A. Fragment of the textile found on the knife in Grave 1-2; B. Textile remains on the bucket fitting from Grave 18. Photo Ł. Antosik, processing E. Wtorkiewicz-Marosik.

have been known, of which 74 are textile remains forming 49 products. In this group, fragments acquired from cemeteries dominate: together they constitute $86 \%$ of the set. ${ }^{7}$ Apart from the Glinno site, textile remains were also recorded in graves discovered in Lutomiersk, Pabianice District, ${ }^{8}$ Lubień, Piotrków Trybunalski District, ${ }^{9}$ Łęczyca, Łęczyca District, ${ }^{10}$ Poddębice, Poddębice District, ${ }^{11}$ and Psary Lechawa, Piotrków Trybunalski District. ${ }^{12}$ The data could be completed with textiles found in the neighbouring area of Wieluń in graves from Dębina, Wieluń District ${ }^{13}$ and Masłowice, Wieluń District. ${ }^{14}$

Clearly, the quantity of archaeological evidence collected so far in the area of interest is scarce and, consequently,

\footnotetext{
${ }^{7}$ Antosik 2015a.

${ }^{8}$ Nahlik 1959a, 141.

${ }^{9}$ Maik 2012.

${ }^{10}$ Abramowicz 1955, 295.

${ }^{11}$ Wiklak 1960, 197-198.

${ }^{12}$ Trębaczkiewicz 1963, 145.

${ }^{13}$ Antosik 2015b, 35.

${ }^{14}$ Antosik 2015b, 33-35.
}

unrepresentative. In order to better depict the disproportion between particular territories, we could mention the example of Silesia, from where as many as 1300 textile fragments are known. ${ }^{15}$ Obviously, the differences result from the state of research on medieval archaeological sites and from their geomorphological conditions that have impact on the preservation of organic products, but also from political significance of particular territories and the level of their economic development.

While the state of preservation of textile remains found in the Glinno cemetery is unfavourable, expert examination permitted to establish precise technological parameters in the case of three of them (Nos. 1, 4-5; see Table 1). An analysis revealed that these are tabby weave textiles of vegetable material. In tabby weave, each weft thread crosses the warp threads by going over one, then under the next, and so on. Such a pattern forms a smooth, uniform surface. Additionally, such fabric is durable which qualifies it for the production of clothing and technical textiles. ${ }^{16}$ The yarn used in both the warp and the weft is Z-twisted (zz), which is very frequent case of textiles made of vegetable material. The other fragments (Nos. 2-3) were so profoundly destroyed that the determination of their parameters or material proved impossible. The only parameter that could be identified was the tabby weave in the case of one of them (No. 2).

The weft yarn is not thicker than the warp yarn in any of the cases. The warp thread is about 0.22 to $0.48 \mathrm{~mm}$ thick, the average being about $0.35 \mathrm{~mm}$. The weft yarn is between 0.23 and $0.52 \mathrm{~mm}$ thick and its average is about $0.37 \mathrm{~mm}$. Thread count could only be measured in one case, and it amounted to 16 threads per $1 \mathrm{~cm}$ in the warp and 14 threads per $1 \mathrm{~cm}$ in the weft. Both the yarn's thickness and thread count are characteristic for vegetable products from Central Poland. ${ }^{17}$ They may certainly be considered as products of local inhabitants. Products with similar parameters are known from numerous early medieval sites from the territory of Poland, just to mention Opole, Opole District, ${ }^{18}$ Gdańsk, Gdańsk District ${ }^{19}$ or Wolin, Kamień Pomorski District. ${ }^{20}$

The presence of the described textile remains encourages their interpretation. In the case of textile fragments discovered as a result of excavation works in cemeteries, these are usually remains of garments. ${ }^{21}$ Textile remains are mostly found on metal elements and the location context is often the only clue as to the function of the fabric.

\footnotetext{
${ }^{15}$ Antosik 2018, 2.

${ }^{16}$ Samsonowiczowa 1977, 9-18.

${ }^{17}$ Antosik 2015a.

${ }^{18}$ Maik 1991, 22, 28, 32, 38-39, 45.

${ }^{19}$ Kamińska and Nahlik 1958, 128.

${ }^{20}$ Nahlik 1959b, 272; Maik 1986, 166.

${ }^{21}$ See, among others, Sikorski 2000; Sikorski 2003; Zawadzka-Antosik 2003; Sikorski 2009; Sikorski et al. 2005.
} 


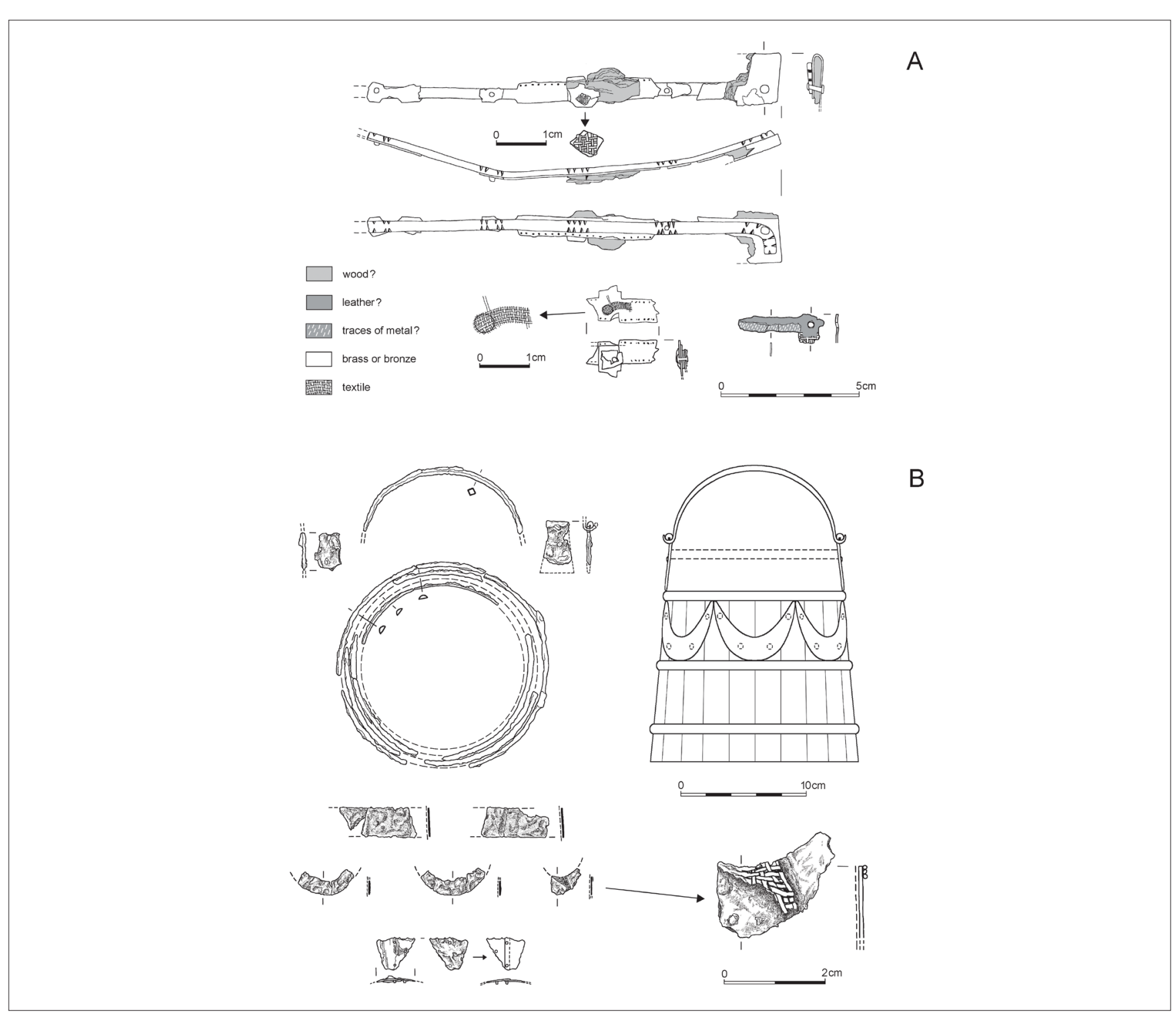

Fig. 4. Cemetery in Glinno: A. Sheath with remains of a knife from Grave 1-2; B. Metal elements of the bucket from Grave 18 (with wooden remains marked with a dashed line) and its reconstruction. Drawing and processing E. Wtorkiewicz-Marosik.

Among the discussed textile remains there are remains preserved on the knife and on the fitting of the sheath inside which the knife was placed (Grave 2). Unfortunately, the state of preservation of these remains does not permit a fully reliable identification of their function. It seems that those observed on the knife may be remains of the sheath. The production of sheaths involved textile lining, as proven by textile remains on the combat knife blade under the layer of a leather sheath discovered in the cemetery in Giecz, Środa District (Grave 77/01). These were fragments and imprints of thick fabric. ${ }^{22}$ Other instances of similar use of textiles were found in Lubien, ${ }^{23}$ Poddębice, ${ }^{24}$ and

${ }^{22}$ Sikorski and Indycka 2005, 212, 216, Tables 6-7, Fig. 13.

${ }^{23}$ Kurasiński and Skóra 2012, 52.

${ }^{24}$ In the case of mounted sheaths from Graves 16 and 25 , leather covered two wooden planks wrapped in linen cloth (Wiklak 1960, 194).
Poznań-Śródka, Poznań District. ${ }^{25}$ Other organic remains have also been preserved on the Glinno knife, most likely leather and wood, which may imply that it was a woodand-leather sheath lined with linen. The use of stronger fabric (possibly, in several layers), provided protection to the knife blade against mechanical damage inside the woodand-leather sheath. ${ }^{26}$

The textile fragment from Grave 2 should be interpreted differently by reason of its location (external surface of the sheath's metal fitting) and finer weave. These are likely remains of garments (or a shroud) that wrapped the body. For instance, textile fragments from the metal fitting of a sheath

\footnotetext{
${ }^{25}$ Sikorski 2003,135 . It is also mentioned that the textile remains on one of the knives suggest that it could have been wrapped in textile before it was placed in the sheath, see Pawlak and Pawlak 2007, 76 - based on an examination by A. Sikorski.

${ }^{26}$ Cf. Sikorski and Indycka 2005, 212, 213.
} 


\begin{tabular}{|c|c|c|c|c|c|c|c|c|c|c|c|}
\hline No. & Location & Material & $\begin{array}{l}\text { Yarn } \\
\text { twist } \\
\text { in the } \\
\text { warp }\end{array}$ & $\begin{array}{l}\text { Yarn } \\
\text { twist } \\
\text { in the } \\
\text { weft }\end{array}$ & $\begin{array}{l}\text { Weave } \\
\text { type }\end{array}$ & $\begin{array}{l}\text { Average } \\
\text { yarn } \\
\text { thickness } \\
\text { in the warp } \\
(\mathrm{mm})\end{array}$ & $\begin{array}{l}\text { Average } \\
\text { yarn } \\
\text { thickness } \\
\text { in the } \\
\text { weft } \\
(\mathrm{mm})\end{array}$ & $\begin{array}{l}\text { Thread } \\
\text { count in } \\
\text { the warp }\end{array}$ & $\begin{array}{l}\text { Thread } \\
\text { count in } \\
\text { the weft }\end{array}$ & Remarks & $\begin{array}{l}\text { Number of } \\
\text { fragments }\end{array}$ \\
\hline 1. & Grave 2 & flax & $\mathrm{z}$ & $\mathrm{z}$ & tabby & 0.48 & 0.52 & 16 & 14 & $\begin{array}{l}\text { Poor state of } \\
\text { preservation. } \\
\text { Fragments of } \\
\text { mineralised textile } \\
\text { preserved on the } \\
\text { knife. }\end{array}$ & 1 \\
\hline 2. & Grave 2 & - & - & - & tabby & - & - & - & - & $\begin{array}{l}\text { Poor state of } \\
\text { preservation. } \\
\text { Fragments of } \\
\text { mineralised textile } \\
\text { preserved under the } \\
\text { sheath's fitting. }\end{array}$ & 1 \\
\hline 3. & Grave 2 & - & - & - & - & - & - & - & - & $\begin{array}{l}\text { Very poor state } \\
\text { of preservation. } \\
\text { Tiny fragment of } \\
\text { mineralised textile } \\
\text { preserved under the } \\
\text { sheath's leather. }\end{array}$ & 1 \\
\hline 4. & Grave 2 & flax & $\mathrm{z}$ & $\mathrm{z}$ & tabby & 0.22 & 0.23 & - & - & $\begin{array}{l}\text { Very poor state } \\
\text { of preservation. } \\
\text { Tiny fragment of } \\
\text { mineralised textile } \\
\text { preserved under the } \\
\text { sheath's fitting. }\end{array}$ & 1 \\
\hline 5. & Grave 18 & flax & $\mathrm{z}$ & $\mathrm{z}$ & tabby & - & - & - & - & $\begin{array}{l}\text { Very poor state } \\
\text { of preservation. } \\
\text { Tiny fragment of } \\
\text { mineralised textile } \\
\text { preserved on the } \\
\text { external surface of the } \\
\text { bucket's application. }\end{array}$ & 1 \\
\hline
\end{tabular}

Table 1. Technological parameters of textile fragments found in the cemetery in Glinno, Sieradz District.

found in Koninek, Poznań District, ${ }^{27}$ were interpreted as remains of clothing. However, another option is also plausible. The knife sheath did not necessarily have to be fastened to the belt of the deceased, as the whole may have been wrapped in a piece of cloth and placed in the grave without being additionally tied with cords. Such a theory appeared in reference to finds from the cemetery in Bodzia, Włocławek District ${ }^{28}$ and Sowinki, Poznań District. ${ }^{29}$ It cannot be excluded, either, that a textile pouch-purse was used. Such explanation is given to

\footnotetext{
${ }^{27}$ Sikorski 2009.

${ }^{28}$ Kowalska 2016a, 257, 260; Kowalska 2016b, 177-178. The textile analysis by J. Maik $(2016,91)$ suggests that these could be traces of clothing or a shroud.

${ }^{29}$ Mentioned are broadcloth (?) rags, in which the knives in sheaths were wrapped, Krzyszowski 1992, 90. However, it should be added that in the light of a textile analysis carried out by J. Maik (1994) and quoted by A. Krzyszowski in a more recent work, fragments of two textile types were found in Graves 148 and 157: these were made of wool and of linen. The woollen textile from Grave 148 (and from Grave 151, where it was also found on a sheath), is thought to be garment remains, while linen would suggest the use of a shroud, Krzyszowski 2014, 150.
}

the presence of fabric remains on sheaths from cemeteries in Giecz (Grave 52/99), ${ }^{30}$ Lubień (Graves 28 and 31), ${ }^{31}$ Łączyno Stare, Mława District (Grave $4 a-b)^{32}$ and others.

The practice of wrapping personal objects placed in graves with textiles to protect them - including the potential ritual meaning of such an act - is suggested by finds from other cemeteries from the Early Middle Ages $^{33}$ as well as earlier periods. ${ }^{34}$ This is also how the presence of textile remains on the bucket fittings from Grave 18 in Glinno could be explained.

The presence of textiles on metal elements of buckets was identified on more than a dozen containers from the Polish territory. Let us mention examples from Cedynia, Site 2a, Gryfino District (Grave 15), ${ }^{35}$ Dębina (Grave 22), ${ }^{36}$ Gnieszowice,

\footnotetext{
${ }^{30}$ Sikorski and Indycka 2005, 211, 214, Table 1.

${ }^{31}$ Kurasiński and Skóra 2012, 52-53.

${ }^{32}$ Kurasiński 2008, 33.

${ }^{33}$ Husár 2008.

${ }^{34}$ Žeiere 2012, 270-271; Grömer 2016, 296-297.

${ }^{35}$ Porzeziński 2006, 29, 174, 178.

${ }^{36}$ Antosik 2015b, 35.
} 
Sandomierz District (Grave 1), ${ }^{37}$ Kałdus, Site 4, Chełmno District (Grave 60), ${ }^{38}$ Kraków-Zakrzówek, Kraków District (Graves 36 and 69), ${ }^{39}$ Lubień (Grave 112), ${ }^{40}$ Nieporęt, Legionowo District (two graves, unnumbered), ${ }^{41}$ Radom, Radom District (Grave 29) ${ }^{42}$ and Sowinki (Graves 7, 70, 135B, $138,148,151$ and 176). ${ }^{43}$

Wherever it was determinable, textile fragments were encountered mostly in upper parts of containers - on rim bands, loops and handles, or, alternatively, on the metal covering or lining. This is why, in the case of several of the aforementioned containers, it was stated that they could have been wrapped in a piece of cloth and deposited into the grave in this way. ${ }^{44}$ It is presumed that the bucket from Cedynia was covered with a small piece of woollen cloth. ${ }^{45}$ It should be added that the practice of placing metal bowls wrapped in textiles in the graves is known from the cemetery in Dziekanowice, Site 22, Gniezno District. ${ }^{46}$ In Grave 60 in Kałdus, a bronze bowl was wrapped in a piece of cloth together with a bucket found inside. ${ }^{47}$ Therefore, it seems justified to presume that the Glinno container was wrapped or covered with a cloth, which was already suggested earlier. ${ }^{48}$ This way allowed not only to protect the container itself, but also whatever could have been placed inside (drinks, food). Nevertheless, a different explanation is also likely - that the textile remains are those of a shroud which wrapped the body together with the adjacent container. ${ }^{49}$ However, it is true that the simultaneous wrapping of the body and the container would have been troublesome, especially if the vessel contained some content. Another point is that the bandaging of the corpse and wrapping it in a shroud were rarely practiced in the Early Middle Ages. The custom of burying the deceased dressed in garments prevailed. ${ }^{50}$

All examined textile finds have been preserved in a very fragmentary state, limiting the possibilities of determining all technological aspects related to their production and, by consequence, the assessment of the level of advancement of local textile production on this basis. We can only form hypotheses as to the primeval use of textiles by the people who used the Glinno cemetery. Nevertheless, it seems justified to claim that the textile finds are local domestic products whose quality does not differ from other products from Central Poland. Even if their function and destination cannot be clearly defined, the context permits to conclude that the textile remains from the inside of the sheath and from the knife indicate utilitarian textile (lining). In the remaining cases, the general funeral function should be assumed, based on the great probability of the practice of wrapping grave goods in a piece of cloth.
${ }^{37}$ Gardawski and Miszkiewicz 1956, 163, 169.

${ }^{38}$ Grupa 2004, 101, 104; Grupa 2007, 275-276.

${ }^{39}$ Morawski and Zaitz 1977, 78, 91.

${ }^{40}$ Kurasiński and Skóra 2012, 201.

${ }^{41}$ Rauhut 1951-1952, 331, 333.

${ }^{42}$ Maik 2011.

${ }^{43}$ Krzyszowski 1997, 662; Krzyszowski 2014, 139, Table 1, 149-150.

${ }^{44}$ Gardawski and Miszkiewicz 1956, 163; Krzyszowski 1997, 663; Krzyszowski 2014, 150-151.

${ }^{45}$ Porzeziński 2006, 174.

${ }^{46}$ Sikorski 2000, 217-221; Sikorski 2002.

${ }^{47}$ Chudziak et al. 2010, 90. According to M. Grupa (2004, $104 ; 2007,276)$ the containers were only covered with a cloth, though textile remains were recorded not only around its edges but also on the bottom part of the bowl.

${ }^{48}$ Kurasiński 2015a, 206; see also Kurasiński 2015b, 187.
${ }^{49}$ Krzyszowski 1997, 663; Krzyszowski 2014, 150; Kurasiński 2015a, 206; Kurasiński 2015b, 152-153, 187.

${ }^{50}$ See Dąbrowska 1997, 10. 


\section{Bibliography}

Abramowicz A. 1955. Badania wykopaliskowe na cmentarzysku Łęczyca-Emaus. "Studia Wczesnośredniowieczne” 3, $294-297$. Antosik Ł. 2014. Glinno, pow. sieradzki, woj. tódzkie, karty z wynikami analiz. Unpublished manuscript in the Institute of Archeology and Ethnology Polish Academy of Sciences, Łódź.

Antosik Ł. 2015a. Wczesnośredniowieczne tekstylia z Polski środkowej w świetle analiz technologicznych $i$ surowcowych. Unpublished manuscript in the Institute of Archeology and Ethnology Polish Academy of Sciences, Łódź.

Antosik Ł. 2015b. Średniowieczne tekstylia archeologiczne z terenu ziemi wieluńskiej. "Rocznik Wieluński” 15, 31-40.

Antosik Ł. 2018. Średniowieczne tekstylia archeologiczne ze Śląska. Stan i perspektywy badań. In: A. Ulanowska, M. Woźniak, M. Żuchowska (eds.), Archeologia włókiennictwa w Polsce - nowe badania, nowi badacze, 27-28 marca 2018, Warszawa. Konferencja ogólnopolska. Książka abstraktów. Warszawa, 2.

Chudziak W., Bojarski J., Stawska V. 2010. Wyposażenie pochówków. In: W. Chudziak (ed.), Wczesnośredniowieczne cmentarzysko szkieletowe w Kałdusie (stanowisko 4). Mons Sancti Laurentii 5. Torun, 79-103.

Dąbrowska E. 1997. Liturgia śmierci a archeologia: uwagi o wyborze miejsca pochowania, orientacji, ułożenia ciała i jego ubiorze w średniowiecznej Europie tacińskiej. "Kwartalnik Historyczny” 104, 3-14.

Gardawski A., Miszkiewicz B. 1956. Cmentarzysko wczesnośredniowieczne w Gnieszowicach pow. Sandomierz. "Materiały Wczesnośredniowieczne" 4, 163-170.

Grömer K. 2016. The Art of Prehistoric Textile Making. The Development of Craft Traditions and Clothing in Central Europe. Veröffentlichungen der Prähistorischen Abteilung 5. Vienna.

Grupa M. 2004. Textiles from the Early Medieval Cemetery at Kałdus, Pomerania, Poland. In: J. Maik (ed.), Priceless Invention of Humanity - Textiles. North European Symposium for Archaeological Textiles VIII. Acta Archaeologica Lodziensia 50 (1). Łódź, 101-104.

Grupa M. 2007. Wczesnośredniowieczne tkaniny z Kałdusa. In: G. Nawrolska (ed.), XV Sesja Pomorzoznawcza: materiały z konferencji 30 listopada-02 grudnia 2005. Elbląg, 275-279.

Husár M. 2008. Niektoré aspekty včasnostredovekých kopiji a oštepov z územia Slovenska - otázky násad a odtlačkov textílií. "Archaeologia Historica" 33, 457-470.

Kamińska J., Nahlik A. 1958. Włókiennictwo gdańskie X-XIII w. Acta Archaeologica Universitatis Lodziensis 6. Łódź.

Kowalska A. B. 2016a. Skórzane elementy stroju w pochówkach na wczesnośredniowiecznym cmentarzysku w Bodzi. In: A. Buko (ed.), Bodzia. Elitarny cmentarz z początków państwa polskiego. Warszawa, 253-264.

Kowalska A. B. 2016a. Możliwość rekonstrukcji stroju osób pochowanych na wczesnośredniowiecznym cmentarzysku w Bodzi. In: F. Franz, K. Kościelniak, Z. Pilarczyk (eds.), Śmierć w dziejach człowieka. Starożytność i średniowiecze. Monografia oparta na materiałach z VIII Międzynarodowej Sesji Naukowej Dziejów Ludów Morza Bałtyckiego. Wolin, 31 lipca-2 sierpnia 2015. Toruń, 164-186.

Krzyszowski A. 1992. Wstępne wyniki badań archeologicznych na wczesnośredniowiecznym cmentarzysku szkieletowym z X/XI wieku w miejscowości Sowinki, gm. Mosina, woj. poznańskie, stanowisko 23A. "Wielkopolskie Sprawozdania Archeologiczne" 1, 83-102.

Krzyszowski A. 1997. Frümittelalterliches Grab eines Kaufmannes aus Sowinki bei Poznań in Großpolen. “Germania” 75 (2), 639-671.

Krzyszowski A. 2014. Naczynia ceramiczne i wiaderka klepkowe z wczesnopiastowskiego cmentarzyska w Sowinkach k. Poznania. In: T. Kurasiński, K. Skóra (eds.), Grób w przestrzeni, przestrzeń w grobie. Przestrzenne uwarunkowania w dawnej obrzędowości pogrzebowej. Acta Archaeologica Lodziensia 60. Łódź, 137-158.

Kurasiński T. 2008. Nie tylko broń. Drobne przedmioty codziennego użytku na wyposażeniu wczesnośredniowiecznego wojownika w świetle znalezisk grobowych z ziem polskich (X-XIII w.). In: W. Świętosławski (ed.), Nie tylko broń. Niemilitarne wyposażenie wojowników w starożytności i średniowieczu. Acta Archaeologica Lodziensia 54. Łódź, 27-49.

Kurasiński T. 2015a. Wiadro obite blaszanymi okuciami z wczesnośredniowiecznego cmentarzyska w Glinnie w świetle dotychczasowych znalezisk europejskich. "Slavia Antiqua" 56, 197-214.

Kurasiński T. 2015b. Burials with Buckets in Early Medieval Poland: A Pagan or Christian Custom? "Analecta Archaeologica Ressoviensia" 10, 137-198.

Kurasiński T. 2016. Dwa interesujące kabłaczki skroniowe z cmentarzyska w Glinnie, pow. sieradzki. Przyczynek do badań nad wczesnośredniowieczna biżuterią z ziem polskich. In: J. Popielska-Grzybowska, J. Iwaszczuk, B. Józefów-Czerwińska (eds.), Meetings at the Borders. Studies Dedicated to Professor Władysław Duczko. Acta Archaeologica Pultuskiensia 5. Pułtusk, $175-181$.

Kurasiński T., Skóra K. 2012. Wczesnośredniowieczne cmentarzysko szkieletowe w Lubieniu, pow. piotrkowski. Łódź.

Maik J. 1986. Wczesnośredniowieczne wyroby włókiennicze w Wolinie. "Materiały Zachodniopomorskie" 32, 155-180.

Maik J. 1991. Tekstylia wczesnośredniowieczne z wykopalisk w Opolu. Warszawa, Łódź. 
Maik J. 1994. Wyniki badań tkanin wykopaliskowych z cmentarzyska w Sowinkach, woj. poznańskie. Unpublished manuscript in the Institute of Archeology and Ethnology Polish Academy of Sciences, Łódź.

Maik J. 2000. Wyniki analiz włókienniczych wczesnośredniowiecznej tkaniny z cmentarzyska w Glinnie, pow. sieradzki. Unpublished manuscript in the Institute of Archeology and Ethnology Polish Academy of Sciences, Łódź.

Maik J. 2011. Wyniki analiz tkanin z wczesnośredniowiecznego cmentarzyska $w$ Radomiu. Unpublished manuscript in the Institute of Archeology and Ethnology Polish Academy of Sciences, Łódź.

Maik J. 2012. Wyniki analiz tkanin z cmentarzyska w Lubieniu, pow. piotrkowski. In: T. Kurasiński, K. Skóra, Wczesnośredniowieczne cmentarzysko szkieletowe w Lubieniu, pow. piotrkowski. Łódź, 339-341.

Maik J. 2016. Tkaniny z cmentarzyska w Bodzi, stan. 1. In: A. Buko (ed.), Bodzia. Elitarny cmentarz z początków państwa polskiego. Warszawa, 91-93.

Morawski W., Zaitz E. 1977. Wczesnośredniowieczne cmentarzysko szkieletowe w Krakowie na Zakrzówku. "Materiały Archeologiczne" 17, 53-169.

Nahlik A. 1959a. Wyniki analizy tkanin. In: A. Nadolski, A. Abramowicz, T. Poklewski, Cmentarzysko z XI wieku w Lutomiersku pod Łodzią. Acta Archaeologica Universitatis Lodziensis 7. Łódź, 140-141.

Nahlik A. 1959b. Tkaniny wykopaliskowe z wczesnośredniowiecznego Wolina. "Materiały Zachodniopomorskie" 5, $257-276$.

Pawlak E., Pawlak P. 2007. Badania archeologiczne na wczesnośredniowiecznym cmetarzysku ,,szkieletowym” z Poznania-Śródki (Rynek Śródecki 4) w 2001 roku. "Wielkopolskie Sprawozdania Archeologiczne" 8, 63-93.

Peacock E. 2014. Experimental Soil Burial Studies for Archaeological Textile Preservation and Research. In: S. Bergerbrant, S. H. Fossøy (eds.), A Stitch in Time. Essays in Honour of Lise Bender Jørgensen. Gotarc series A: Gothenburg Archaeological Studies 4. Gothenburg, 1-22.

Porzeziński A. 2006. Wczesnośredniowieczne cmentarzysko szkieletowe na stanowisku 2 a w Cedyni, województwo zachodniopomorskie. Szczecin.

Rauhut L. 1951-1952. Wczesnośredniowieczne cmentarzysko szkieletowe z przełomu XI-XII w. w Nieporęcie. "Wiadomości Archeologiczne" 18, 323-344.

Samsonowiczowa A. 1977. Ze studiów nad odzieżą ludności zamieszkującej ziemie polskie we wczesnym średniowieczu. "Prace i Materiały Muzeum Archeologicznego i Etnograficznego w Lodzi. Seria Archeologiczna” 24, 5-40.

Sikorski A. 2000. Wyniki analiz fragmentów tkanin z grobu 17/98 w Dziekanowicach, gm. Łubowo, woj. wielkopolskie, stan. 22. "Studia Lednickie" 6, 213-224.

Sikorski A. 2002. „, Opakowanie” tekstylne misy mosiężnej z wczesnośredniowiecznego grobu szkieletowego na cmentarzysku „,Mały Skansen” w województwie wielkopolskim. In: J. Olczak (ed.), Studia z historii architektury i historii kultury materialnej. Archaeologia Historica Polona 12. Toruń, 135-140.

Sikorski A. 2003. Nie tylko o tekstyliach wykopaliskowych z Wielkopolski. "Wielkopolski Biuletyn Konserwatorski” 2, $123-142$.

Sikorski A. 2009. Analiza fragmentów płótna z grobu 11 na cmentarzysku wczesnośredniowiecznym w Koninku, stan. 65 , gm. Kórnik, woj. wielkopolskie. "Folia Praehistorica Posnaniensia" 15, 296-298.

Sikorski A., Indycka E. 2005. Tkaniny z cmentarzyska szkieletowego w Gieczu, gm. Dominowo, woj. wielkopolskie (stan. 4). "Studia Lednickie" 8, 207-218.

Sikorski A., Wrzesińska A., Wrzesiński J. 2005. Fragmenty tkanin z dwóch wczesnośredniowiecznych grobów cmentarzyska „Maty Skansen”. Kilka uwag o ubraniu wczesnośredniowiecznym. "Studia Lednickie” 8, 149-166.

Trębaczkiewicz T. 1963. Cmentarzysko wczesnośredniowieczne we wsi Psary, pow. Piotrków Trybunalski. "Prace i Materiały Muzeum Archeologicznego i Etnograficznego w Łodzi. Seria Archeologiczna" 9, 131-166.

Wiklak H. 1960. Cmentarzysko z XII i XIII w. w Poddębicach. "Prace i Materiały Muzeum Archeologicznego i Etnograficznego w Łodzi. Seria Archeologiczna" 5, 183-207.

Zawadzka-Antosik B. 2003. Czekanowskie cymelia. In: M. Dulinicz (ed.), Słowianie i ich sąsiedzi we wczesnym średniowie$c z u$. Warszawa, Lublin, 327-333.

Žeiere I. 2012. Latvia. In: M. Gleba, U. Mannering (eds.), Textiles and Textile Production in Europe: From Prehistory to $A D$ 400. Ancient Textiles Series 11. Oxford, Oakville, 266-274. 


\section{Streszczenie}

\section{Znaleziska tekstylne z wczesnośredniowiecznego cmentarzyska w Glinnie, pow. sieradzki. Nowe dane do badań nad włókiennictwem Polski centralnej}

Artykuł poświęcony został szczegółowemu omówieniu pozostałości wyrobów włókienniczych, pochodzących ze szkieletowego cmentarzyska w Glinnie, stan. 15 (gm. Warta, pow. sieradzki, woj. łódzkie), użytkowanego w okresie między połową XI a połową XII w. Stanowisko odkryto przypadkowo w 2000 r. podczas robót ziemnych.

Rozpatrywane znaleziska odnotowano w dwóch grobach. W grobie nr 1-2 (podwójnym) fragmenty silnie zmineralizowanych tkanin stwierdzono przy nożu oraz pod i na powierzchni mosiężnego okucia drewniano-skórzanej pochewki. Ponadto jeden nikły fragment uchwycony został pod warstwą skóry. Z kolei w obiekcie nr 18 szczątki zmineralizowanych resztek tekstylnych zaobserwowano na zakończeniu półksiężycowatej aplikacji z metalu (na powierzchni zewnętrznej), pochodzącej z wiadra.

Łącznie z cmentarzyska w Glinnie pochodzi pięć fragmentów tkanin. Zespół ten stanowi zatem skromną grupę zabytków, która jednak znacząco uzupełnia bazę źródłową wczesnośredniowiecznych materiałów włókienniczych z Polski centralnej.

Stan zachowania odkrytych na cmentarzysku w Glinnie pozostałości tkanin przedstawia się niekorzystnie, aczkolwiek dokładne parametry technologiczne udało się ustalić w przypadku trzech z nich (nr 1, 4-5). Analiza wykazała, iż mamy do czynienia z wyrobami utkanymi w splocie płóciennym z surowca roślinnego (len). Były to zapewne lokalne produkty właściwe dla domowej wytwórczości, nieodbiegające swą jakością od innych wyrobów środkowopolskich. Ich funkcja nie jest jasna, przypuszczalnie jednak fragmenty tekstylne z wnętrza pochewki, a także z noża wskazują na tkaninę stricte użytkową (wyściółka). W pozostałych przypadkach ogólnie należy przyjąć przeznaczenie funeralne, zważywszy przede wszystkim na duże prawdopodobieństwo owijania przedmiotów w tkaninę. 
